\title{
PLACE MARKETING STRATEGY OF LATGALE REGION DEVELOPMENT
}

\author{
JEKATERINA VOZN̦UKA ${ }^{1}$
}

Baltic International academy (Latvia)

\begin{abstract}
In this paper the author has developed place marketing strategy model for Latgale region that could be used as the base for working out programs of social and economic development. The author defines essence and specific of the marketing places conception, analyses Latgale region as marketing object based on segmentation and research of target markets. Interrogatory methods were used to investigate target audience of the region. The results of analysis of Latgale region and the results of the research of its target markets became empirical base for Latgale region place marketing strategy model. The developed place marketing strategy for Latgale region is based on regular and systematic investigation of the condition of the territory and its development tendencies in order to take rational decisions and to choose the priority development directions in the conditions of limited resources in accordance with real or potential demand of the target markets and to allocate the existing resources for its satisfaction.

KEW WORDS: development, target market, positioning, place marketing.
\end{abstract}

JEL CODES: R190, R580, M310

\section{Introduction}

Today the non-homogenous regional development is one of the most significant problems in many countries. In the conditions of economic crisis the situation in low-developed regions becomes even more complicated. The growing competition, the increase of social problems, the deficit of financial support and disbalance of budget enhance the problem. In these conditions the change of approaches and paradigms is essential both in economics and management as the perception of humans, their behavior and motives have changed. The understanding of the aforementioned situation enables to find new resources and opportunities. Economic crisis makes corrections in development programs and scenarios, and only appropriate strategies, adjusted to current situation, will matter.

To stimulate regional development and to remedy crisis situation, it is possible to use marketing approach, considering the advantages of territory as a project that certain target audiences are interested in.

Place marketing is a little developed economic tool in Latvia and a new direction of Latvian economic science. The problem of the use of place marketing in Latvia is topical due to several reasons. First of all, globalization and capital integration process is developing; secondly, the competition between different territories for resources and buyers increases; thirdly, the EU regulations stimulate free circulation of capital, goods and people and, therefore, it becomes significant to pay more attention to place marketing sphere; fourthly, there are internal problems in the country, including the above mentioned non-homogenous development of Latvian regions as well as low loyalty of population to the regions, a high level of migration etc.; fifthly, a complicated economic situation in the country requires the search of new development approaches.

\footnotetext{
Jekaterina Voznuka - Baltic International academy, docent, doctoral degree in Economics (Dr. oec.), marketing consultant. Scientific interest: marketing strategy.

E-mail: katja.bki@inbox.lv

Tel.: +371267722 41
} 
The level of regional economic development is characterized by the following indicators: gross domestic product, the number of economically active companies, the amount of non-financial investments, population and the rate of unemployment. According to the most of these indicators, Latgale region has the lowest position amongst the other regions of Latvia, despite the fact that the guidelines of regional development of Latvia were approved and the conception of regional development policy was adopted more than ten years ago.

The object of the research is Latgale region of Latvia.

The purpose of the article is to research the opportunities of the use of place marketing in Latgale region development. In order to achieve this purpose, the following tasks have been set up:

1. To analyze the opportunities of the use of place marketing in the development of territories by generalizing and comparing modern place marketing conceptions and developing a precise overall marketing technology for use in territory development programs;

2. To research Latgale region as a marketing object and to analyze the target markets of the region and their needs;

3. To analyze the real and potential product of Latgale region from the standpoint of households, business environment representatives and visitors;

4. To develop place marketing strategy model for Latgale region, aimed at the stimulation of its social and economic development, by generalizing and systemizing theoretical and practical information, based on the results of the conducted researches.

In the research conventional theoretical and empirical qualitative and quantitative methods have been used, including informative analysis and generalization of monographs and other sources; comparative analysis and synthesis method; processing of statistical data, using comparison analysis; researches, based on secondary information; interrogation by using questionnaires and focus groups, based on descriptive and analytical statistical method.

\section{Place Marketing Conception}

In the conditions of limited resources one of the main territory management tools is the improving of the quality of the existing resources ad the creation and attraction of new resources. The enhancement of the level of territory development can be achieved, using marketing approach.

The novelty of place marketing conception is related to the fact that the territory is considered not as an administrative unit, but also as an economic subject and object that satisfies the needs of external and internal audience in order to increase its wealth.

Based on the research and generalization of place marketing conception (Ashworth, Voogd, 2007; Kotler, 2004; Olins, 2003) and definitions, the author suggests the following interpretation: place marketing is a target-oriented action that includes market research, product planning, creation, management and promotion in the market in order to satisfy the needs of interested target audiences and to achieve the objectives of the territory, related to its economic and social development (Вознюк, 2008: 283).

The target markets of place marketing cover a very wide scope of audiences, as different features of territory and the objects of different spheres can draw one's attention depending on the objectives (Kotler, 1993: 22-33). From the author's point of view, first of all target markets should be distinguished depending on their objective related to the territory; in order to facilitate segmentation process, the author suggests to consider the target markets, taking into account their "location" - in the territory our out of the territory. Therefore the target markets can be classified to internal and external markets, as shown in the scheme, developed by the author (Figure 1).

Inside of each target market several segments can be distinguished, that could be considered as actually or potentially attractive for the territory, and visa versa - the segments that consider the territory as attractive for their specific objectives. At the same time one should recognize that the advantages of one of the same territory cannot be interesting for all markets. The so-called non-differenced marketing strategy is not available for small territories with limited resources and weakly exposed potential, low competitiveness and economic development. 


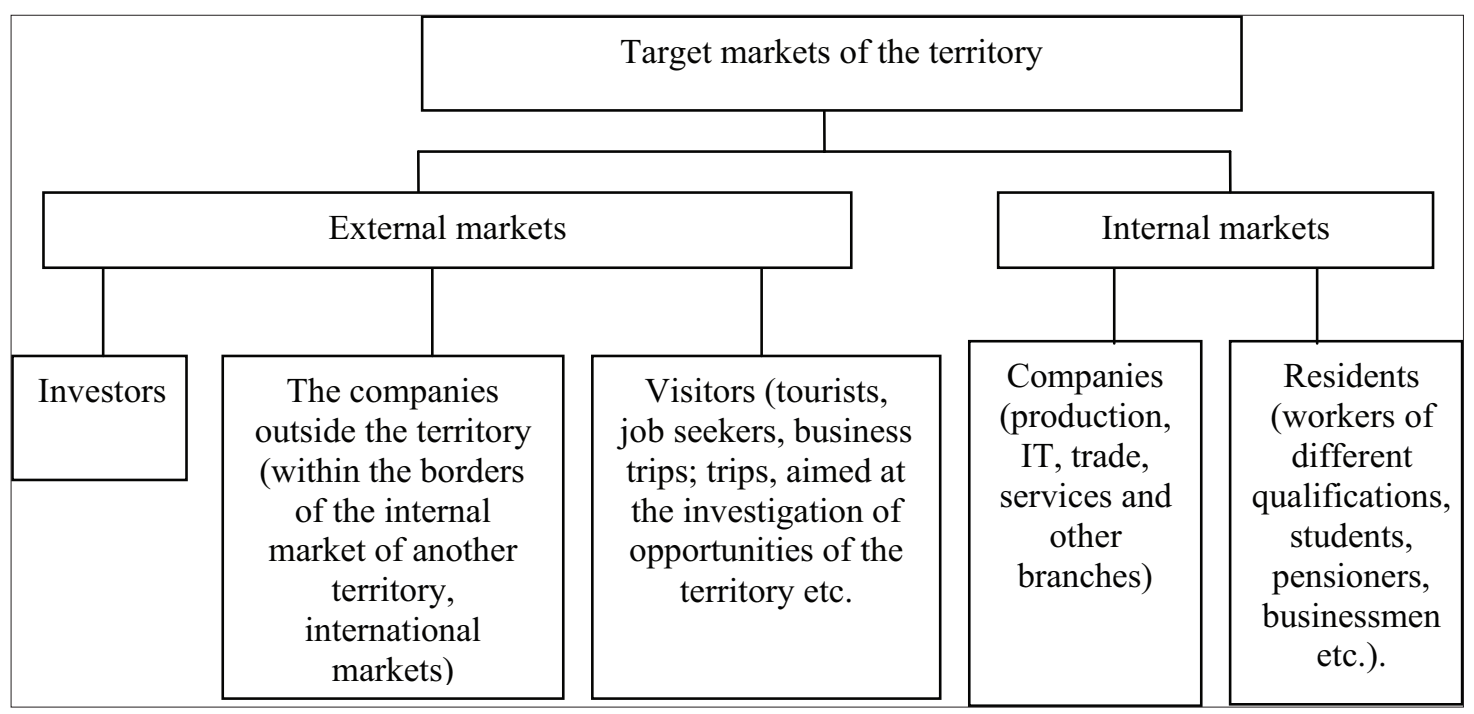

Figure 1. Target Markets in Place Marketing

Source: Praude, Vozņuka, 2008: 105

The author suggests using the marketing complex approach "4P" (Product, Price, Place, Promotion) in place marketing, taking into account the particularities and specifics of territory.

Product is the variety of resources and products of the territory, their amount and quality the target markets are interested in. As an example, geographic location, nature objects, infrastructure, living standards, business activity and many other advantages that can stimulate the interested groups to use the territory for their objectives can be mentioned.

The determination of product price depends on the particularities of the consumers of this territory. For households these are life values, the level of income and social benefits as well as the value of specific products. For tourists service prices as well as the presence and availability of cultural and historical monuments will matter. Potential investors will consider the attractiveness of the value of the available resources, tax rates, the features of local legislation and regulations that impose limitations or stimulate investments etc.

Product place is the concentration and availability of material resources, intellectual and technological potential for interested groups and their locations. It should be taken into account that it is impossible to move the product (territory advantage) and to offer it to potential consumers within the same territory. A reverse process takes place, i.e., the consumers should move around in order to get the product of the territory. An exception is the activities of territory in export market, however, even in this case the location of territory is of great importance as the distance from it and the expansion of the covered markets influence the price of the product, therefore the territory can reduce the competitiveness of its product.

Product promotion is a complex approach of marketing communications that includes the creation of information and distribution channel, its content, form, bearer, amount and implementation time.

The working out and planning of place marketing strategy, aimed at region development, is based on extended researches in different fields. The directions of the researches (Figure 2) determine marketing planning stages. 


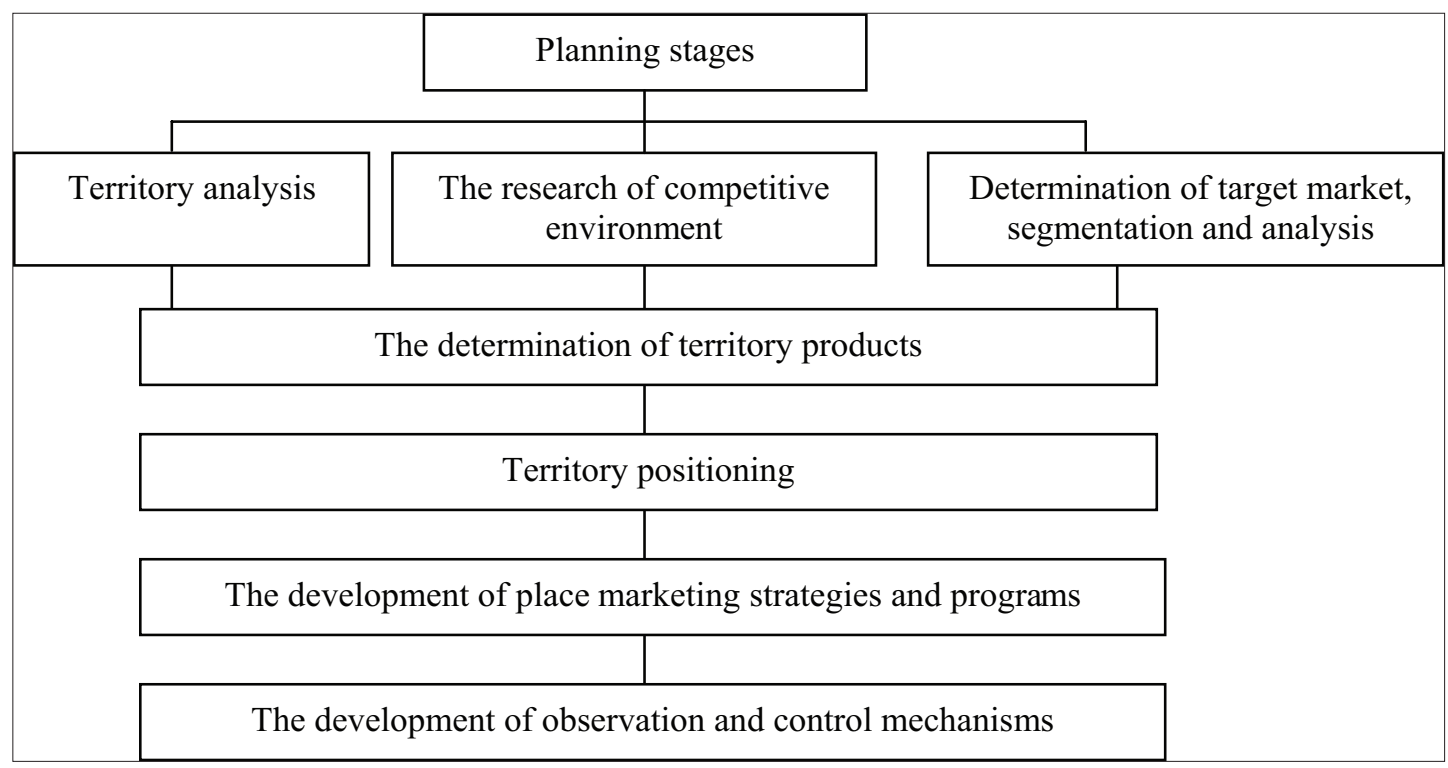

Figure 2. Place Marketing Conception Development Stages

Source: the scheme is developed by the author

Compared to strategic planning, that is widely used in the working out of territory development strategies and in regional policy, the place marketing conception is more oriented in market demand, adjusted to market conditions and, therefore, in author's opinion, can provide more efficient results.

\section{The Analysis of Latgale Region as Place marketing Object and its Target Markets}

In the analysis of Latgale region as place marketing object the main attention was paid to the segmentation of target markets of the region and the analysis of real and potential product of Latgale region from the standpoint of households, business environment representatives and visitors.

In the process of development of place marketing strategy for households 'target market, first of all, one should determine the possible product of the territory, i.e., the advantages and disadvantages that can satisfy the needs of the households for the place of residence, or, on the contrary, create negative attitude and stimulate them to change their place of residence.

In order to research the households' attitude and their satisfaction with their place of residence, interrogations have been made in focus groups and using questionnaires (quota selection method, the selection scope -400 respondents).

The analysis of the results has showed that the contentment with the place of residence is determined by many factors. The following factors are the most important ones:

- The existence of working places;

- The availability and quality of medical services;

- Ecologically sound environment;

- Good condition of roads and the availability of urban amenities;

- Security and low crime level.

At the same time, along with social and economic indicators satisfaction with the place of residence is also influenced by the features that mostly relate to human communication environment, affinity, nationality and mother tongue.

The correspondence of all factors to Latgale region has been evaluated. The results show that the total level of evaluation of the factors that determine satisfaction with the place of residence in Latgale is lower 
compared to the households' demands. Such factors as "the existence of working places" and "good condition of roads and the availability of urban amenities" do not correspond to the situation in the region at all these are on the last positions; amongst the most demanded factors only "ecologically sound environment" has been treated as the feature that corresponds to Latgale district. The availability and quality of telecommunications, bank services and consulting as well as the existence of preschools are the closest ones to the households' requirements in terms of situation evaluation; however, it should be noted that these features have a moderate influence on the satisfaction of people with their place of residence.

Despite the fact that the largest part of population associate Latgale with their home and Motherland, the level of loyalty can hardly be considered as high, as a total of approximate $35 \%$ of respondents consider the opportunity to leave Latgale.

Based on the analysis of the factors that determine satisfaction with the place of residence and the features of Latgale region in respondents' opinion, the author concludes: Latgale as a place of residence is evaluated negatively as the most significant factors that determine the satisfaction of people with their place of residence in respondents' valuations are amongst the deficiencies of the region.

No doubt, in case the territory does not have any other real advantages the strategy of region positioning as a place of residence can be based on the features of secondary importance (for example, quality of telecommunications and bank services), creating the demand for these features, emphasizing their importance and necessity. This technology is based on reorientation of public opinion and attention to other less important aspects in order to switch attention from problematic branches and to gain time for liquidation of negative features. It is not expedient to assume the probability of sustainable success without changes in living conditions of Latgale region, implementing the strategy, based on the features of secondary importance, as well as to hope for endless loyalty of population.

The mentioned problematic issues stimulate the development of negative image of Latgale region, as perceived by the population, and require a prompt solution, as all these directions have a great importance in the planning of region development strategy.

The behavior and activities of local and foreign businessmen, export and investors' target markets are interconnected; therefore the author analyzed these markets jointly.

Business activity is the main condition of the increase of economic development of the region. The general economic situation in Latgale is described with the same tendency as is in the country overall, both in terms of economic growth and crisis. However, economic situation in Latgale is worse than in Latvia overall.

Today the local businessmen perceive ambiguously not only business development, but also existence in Latgale. Unfavorable forecasts, the general reduction of economic activity as well as the drop in purchase power of the households enhance the negative attitude of businessmen and their willing to search for the solution of this unfavorable situation.

As a rule, amongst the most important factors for local and foreign businessmen, export and investors' target markets the following factors can be distinguished: the conditions of business startup and favorable business environment and tax system; the situation in labor market and the availability of labor force; the level of development of infrastructure and bank sector and the availability of finance; competitiveness policy and the efficiency of normative acts and courts country; the policy of development of small and middle enterprises (SME) and public organizations, acting in the interests of businessmen and in order to provide support for business development.

Most of the mentioned factors are not exposed in territory level and are related to the overall territory of the country, therefore they cannot objectively distinguish Latgale region in any terms (positive or negative) amongst the other regions of Latvia and they should not be considered as the factors, determining business development in Latgale. However, there are also other objective factors that can influence the competitiveness of Latgale region as a place for business location amongst the other regions of the country. According to the results of the analysis there are the following advantages for business environment in Latgale region:

- Business development traditions: experience and the availability of qualified labor in different branches of national economy;

- Geographic location. 
The territory can assign to business development traditions leading role in the determination of territory product, as the development of certain branches in the region does not only influence the direction of business image development, but also points to the experience and the existence of qualified labor in national economy branches. Amongst the major branches wood processing, metal processing and food processing industry as well as furniture production, transportations and transit can be mentioned.

Geographic location of Latgale region is an objective advantage that can be used for many different business activities (export stimulation, the foundation of co-products and additional products manufacture and investments in these companies etc.). At the same time transportations and transit should be considered as one of the most important factors in the determination of the supply of place marketing product of the region.

Amongst the other regions of Latvia, Latgale has all rights to be considered as the most promising region in terms of tourism development. The region offers various recreation options, especially active recreation outdoors and rural tourism.

The natural conditions and historical traditions of Latgale region also influence the development of tourism sphere and the formation of a certain image in terms of visiting and resting in the region. One of the types of tourism that is developing in Latgale and is primarily associated with this region is rural tourism.

The analysis of supply of Latgale companies, working in tourism sphere, enables to conclude that they try to use the potential of nature, as recreation in Latgale is mostly related to rural tourism and outdoor activities.

Overall, the following Latgale region positioning features can be distinguished:

- Latgalian language;

- The land of blue lakes;

- Picturesque landscapes;

- Ceramics - the traditional "business card" of Latgale;

- Aglona church (is amongst the top 10 tourism objects in Latvia).

The information on Latgale region as a resting place, provided by mass media, is limited and monotonous and it does not contain any special features that could make people interested to spend time in Latgale. The activities of public and private sector in this field are not coordinated, both work on its own.

In order to determine and investigate the target market of potential visitors of Latgale region, the author used an interrogation, based on determinate selection. The analysis of motivation of spending free time in Latgale shows that the main motive is related to outdoor resting. Next significant motives are active resting, interesting excursions as well as beautiful and clean environment. If such motives as resting at the lake or river coincide with the components of Latgale region product and could be used in positioning, then active resting and interesting excursions should be considered as a potential component of the product and segment that is based on these motives and represents potential market audience.

The main motive to spend free time in Latgale region has been fully justified, as this is also the main association with Latgale as "the land of blue lakes". The strong association with the land of blue rivers points to a certain image, based on natural resources that in turn determine the main positioning component. Secondly, negative associations are mentioned relatively more seldom by the residents of the other regions of Latviathis means that such significant factors as low level of infrastructure development and low living standards do not influence the image of Latgale region so far.

\section{Place marketing objectives and marketing complex of Latgale Region}

Despite the crisis situation, the author thinks that Latgale region still has potential that can be used for its development. No doubt, the accrued problems considerably exceed the opportunities to solve them; therefore it is extremely important to determine the priority directions correctly and to allocate resources for the activities that are the most advantageous in terms of territory development and profitability. In the conditions of limited resources the development of territory can be achieved by using place marketing conception and working out development strategy on its base. 
In author's opinion, the formulation of place marketing objectives for Latgale region could be the following:

- To provide the maintenance of real products, improving their quality and availability;

- To retain the existing consumers by enhancing the level of satisfaction of their needs;

- To develop relations with place marketing activities intermediaries and facilitators (specialized institutions on the level of region, state level and international level);

- To increase the portion of attracted and retained consumers in each target market;

- To enhance the level of loyalty of consumers of territory products;

- To investigate the tendencies of region image formation in different audience and to make efforts to improve it;

- To develop and create new product components according to the needs and demand of target markets.

Based on the main marketing mix elements („4P”), planning territory development strategy on the base of place marketing conception, in author's opinion, it is expedient to pay attention to the mentioned strategic objectives as they determine the direction of development, the specifics of strategy and its realization opportunities (potential).

When planning the development of place marketing strategy for Latgale region related to internal markets households and companies, it should be taken into account that the territory products these audiences are interested in are related to several conditions in terms of life comfort, ability to work and development standpoint.

Today the region can offer the following real products to the households:

- Ecologically sound environment;

- School and educational establishments, their high quality;

- The availability and quality of banks and other financial services;

- Life together with relatives and friends.

When developing the most demanded product components, real product should be maintained as supported in order not to loose it in the most pessimistic case. In present situation, in order to develop the image of the region, these real features should be used in positioning process, as they, in spite of their secondary meaning according to the residents' valuations, enable to create basis for positive image of Latgale region.

The product strategy, related to business audience requires the biggest attention and resources to be involved. It is explained by the fact that Latgale region cannot offer to business target markets any especially attractive features. The location of the region at the border is traditionally used for transit (in other words, due to the absence of alternative), however, the completion of this function is also on a rather low development level, that in turn impacts the formation of business image of the region. Therefore today real product in this market today is formed by just one component - geographic location that is important for certain branches, for export or transit. All the other territory product components that could be interesting for business market segments are to be developed.

Recreation outdoors forms a real product for both real and potential visitors of the region, as there are market expansions opportunities - the product can be promoted outside of Latvia. The rural tourism feature of Latgale region, compared with the supply of other territories of Latvia, is based on multiple lakes and the best remembered by many people name "the land of blue lakes", as well as such features as different culture (as it is believed that the region has not only its own language, but also its specific cultural traditions).

As the analysis of the results of researches showed, the following components of potential product related to the target segments of recreation enthusiasts and tourists should be developed:

- Fascinating tour, based on visiting significant places;

- Event marketing.

Taking into account the specifics of territory and its products, the development of product distribution channels strategy is not demanded, as the product is related to the location of territory and a reverse process takes place interest audiences should come for the product. The second issue - how advantageous, convenient and available in terms of geographic location the product is situated and can be accessed, taking into account the conditions of 
infrastructure development and transport connection. An interested person should make certain efforts, spend some resources as well as apply some skills and qualifications in order to visit some significant place, move to a new place of residence or to locate a production workshop in a certain territory. This aspect, related to marketing complex element - place, points once more to the interrelation and sometimes integrity of marketing complex elements.

Pricing strategy is one more important part of marketing complex and a very complicated component, as the revenues of territory directly depend on price. A clever pricing, from one side, helps the territories to compete between each other for the attraction of target markets, but, from the other side, on regional level pricing policy is mostly determined by state policy and in some cases it is impossible to offer to the interested audiences price advantages. At the same time the status of backward territories of Latgale region with a low level of social and economic development enables to hope for both governmental support and a wider use of European funds allocations for the realization of their programs that are fully or partly aimed at the achievement of place marketing objectives.

Promotion strategy is developed in order to provide the target markets with information on territory product. This strategy requires decision taking on the use of the main types of marketing communication, i.e., advertisement, sales promotion or stimulation measures, public relations, direct marketing and personal sales/servicing.

The main communication objectives related to the target markets of Latgale region can be defined as follows:

- For the households' target market: to provide people with a certain understanding of their place of residence, the advantages and disadvantages of the region and an adequate valuation of them;

- For business environment target market: to inform on advantages of the region in terms of realization of business activity, based on competition and using marketing mix components "price' and "placement".

For the target market of visitors and recreation enthusiasts: to stimulate them to spend their free time in Latgale, therefore the main communication tools are related to sales promotion technologies.

In Table 1 the model of place marketing strategy development for Latgale region is given, based on the results of the researches.

Table 1. Place Marketing Strategy Model for Latgale region

\begin{tabular}{|l|l|l|l|l|l|}
\hline \multicolumn{1}{|c|}{$\begin{array}{c}\text { Target } \\
\text { market }\end{array}$} & $\begin{array}{l}\text { Segmentation } \\
\text { criterion }\end{array}$ & \multicolumn{1}{|c|}{ Objective } & \multicolumn{1}{|c|}{$\begin{array}{c}\text { Positioning, based on } \\
\text { territory product }\end{array}$} & $\begin{array}{l}\text { Territory } \\
\text { image creation } \\
\text { strategy }\end{array}$ & $\begin{array}{l}\text { Communication } \\
\text { types }\end{array}$ \\
\hline $\begin{array}{l}\text { Population } \\
\text { (households) }\end{array}$ & $\begin{array}{l}\text { People, living in } \\
\text { the territory of } \\
\text { the region (real } \\
\text { consumers) }\end{array}$ & $\begin{array}{l}\text { To retain in the } \\
\text { territory }\end{array}$ & $\begin{array}{l}\text { Clean environment and } \\
\text { beautiful landscapes } \\
\text { The availability and } \\
\text { quality of modern services } \\
\text { Motherland, relatives and } \\
\text { friends }\end{array}$ & $\begin{array}{l}\text { Image } \\
\text { reformation }\end{array}$ & $\begin{array}{l}\text { Educative, } \\
\text { explaining and } \\
\text { persuasive }\end{array}$ \\
\hline $\begin{array}{l}\text { Business } \\
\text { audience }\end{array}$ & $\begin{array}{l}\text { Businessmen, } \\
\text { export market, } \\
\text { investors }\end{array}$ & $\begin{array}{l}\text { To develop } \\
\text { relation and to } \\
\text { attract }\end{array}$ & $\begin{array}{l}\text { The proximity of the markets } \\
\text { of the EU and CIS countries } \\
\text { Cheap and highly qualified } \\
\text { labor }\end{array}$ & $\begin{array}{l}\text { Image } \\
\text { development }\end{array}$ & Informing \\
\hline $\begin{array}{l}\text { Visitors/ } \\
\text { recreation } \\
\text { enthusiasts }\end{array}$ & $\begin{array}{l}\text { Place of } \\
\text { residence: } \\
\text { Latgale, other } \\
\text { regions of Latvia, } \\
\text { foreigners }\end{array}$ & $\begin{array}{l}\text { To increase } \\
\text { the number of } \\
\text { segments }\end{array}$ & $\begin{array}{l}\text { Hospitable land of blue } \\
\text { lakes with ecologically } \\
\text { sound environment, its } \\
\text { own language and cultural } \\
\text { traditions }\end{array}$ & $\begin{array}{l}\text { Image } \\
\text { improvement } \\
\text { and } \\
\text { enhancement }\end{array}$ & Stimulating \\
\hline
\end{tabular}

Source: the table is composed by the author

In present situation the objective of place marketing of Latgale region is based on retention of the target market, using the according products. These products obviously meet the requirements of the target markets 
only partly, however, the creation of new products requires time and resources, but the loss of segments of the target markets in current economic and social situation endangers not only the development opportunities of the territory, but also its survival.

\section{Positioning strategy and image of Latgale region}

Positioning strategy can be distinguished separately, as it has its own specifics in place marketing. When forming the position of territory, one should choose only those facts and events that correspond to the interests of each determined and deeply researched audience.

Based on product strategy and the results of the research, the comparison of real and desired position, the analysis of association rows, territory advantages and opportunities and tendencies of its development, the author has developed the main positioning components for each target market:

1) For households' target market:

- The land of blue lakes, clean environment and beautiful landscapes;

- Motherland, relatives and friends;

- The availability and quality of modern services.

2) For business environment target market:

- The proximity of the market of the EU and CIS countries;

- Cheap and highly qualified labor;

- Priority branches: logistics, wood processing, food industry, metal processing, rural tourism.

3) For visitors' target market:

- The land of blue lakes and ecologically sound environment;

- Own language and cultural traditions;

- Hospitality.

The results of the research showed that the image of Latgale region is negatively evaluated by the households as the most important features that are necessary in order to provide that a person is satisfied with his or her place of residence are amongst the disadvantages of the region - they are not developed or are lowdeveloped. This makes the base for the conclusion on image creation strategy and the most complicated task for its implementation - to reform the image of the region.

The region is evaluated more positively by potential visitors and recreation enthusiasts, but recreation place position is not that strong and cannot attract enough visitors. Therefore image strategy for this target market is to improve and enhance favorable attitude to the region.

In business sphere Latgale region is evaluated ambiguously that point to a contradiction in region image. This in turn does not stimulate a stable interrelation with this sector's representatives that could provide the region with the results of positive long-term cooperation and development. Therefore image development strategy for this target market requires initial efforts - image conception development and formation.

Territory image formation technology is based on the chosen position, as its components make the major platform the territory image is formed around. The achievement of balance between the real and desirable position is the first step in image formation process. It is followed with the promotion of position, using integrated marketing communication.

\section{Integrated marketing communication}

Integrated marketing communication reflects the essence of place marketing strategy, joining together both all elements of conception and separate activities, that in certain conditions get transformed to competitive advantages or emphasize and draw attention to the components of product, offered by the territory, the target markets are interested in. 
No doubt, one cannot affirm that marketing communication programs, aimed at the presentation of the region, information of different audiences and drawing their attention, have not been used in Latgale region before.

Latgale region participates in several projects, especially based on near-border cooperation. This opportunity obviously influences region development and enables to find new approaches as ideas. However, from place marketing standpoint the following negative aspect should be mentioned: the participation of regional administration and organizations in the projects is not structured and non-systemized that, in author's opinion, does not stimulate the formation of identity of the region, even more - it creates an uncertain image that often contains ambiguous formulations and mottos. The author can explain it with the lack of unified conception and the variability of authorized organizations, amongst which each organization has its own opinions on Latgale image creation and the opportunities and ways of its development. Therefore the activities that directly or indirectly perform the functions of impact on target markets, are not coordinated and, due to the mentioned deficiencies, are not only unable to draw attention to the region, but also can reduce interest due to this uncertainty, especially in cases of repeated appeal.

Based on the conception of the choice of integrated marketing communication tools and taking into account the main directions of the developed Latgale region place marketing strategy, a model of planning of marketing communication distribution tools is suggested in Table 2.

As can be seen in table 2, nearly in all cases the traditional communication tools - TV as well as printed press - newspapers and magazines - can be used. The organization of special events and taking part in these events is specific depending on the segment, as for local population these could be local public events, for business environment representatives - visiting presentations, participation in thematic exhibitions and other events that can provide direct contact, but for visitors it could be the organization of attractions and participation in thematic tourism exhibitions. At the same time Internet is of great importance, not only based on the features of the target markets of the region and communication objectives of the target markets, but also taking into account the role of Internet and its obvious advantages in terms of information distribution, the coverage of audience and interest to the home pages, banners and other tools.

Table 2. The Planning of Integrated Marketing Communication Distribution Tool

\begin{tabular}{|c|c|c|c|c|}
\hline Target & Target market & \multicolumn{2}{|c|}{ Communication objective } & Communication distribution tools \\
\hline \multirow{2}{*}{ 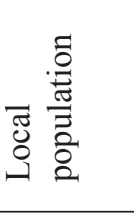 } & $\begin{array}{l}\text { With positive/ } \\
\text { neutral attitude }\end{array}$ & \multirow{2}{*}{$\begin{array}{l}\text { To inform, to } \\
\text { educate, to } \\
\text { explain and to } \\
\text { persuade }\end{array}$} & $\begin{array}{l}\text { To enhance or to create } \\
\text { positive attitude }\end{array}$ & $\begin{array}{l}\text { TV, radio, newspapers and } \\
\text { magazines, outdoor advertisement, } \\
\text { special events, Internet }\end{array}$ \\
\hline & $\begin{array}{l}\text { With negative } \\
\text { attitude }\end{array}$ & & To change negative attitude & $\begin{array}{l}\text { TV, newspapers and magazines, } \\
\text { special events, Internet }\end{array}$ \\
\hline \multirow{2}{*}{ 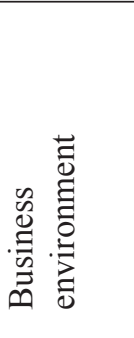 } & $\begin{array}{l}\text { Audience } \\
\text { with previous } \\
\text { experience, } \\
\text { relatively } \\
\text { informed } \\
\end{array}$ & \multirow[t]{2}{*}{$\begin{array}{l}\text { To inform, to } \\
\text { draw attention }\end{array}$} & To improve the attitude & $\begin{array}{l}\mathrm{TV} \text {, radio, newspapers and } \\
\text { magazines, outdoor advertisement, } \\
\text { special events, Internet, printing } \\
\text { production and souvenirs }\end{array}$ \\
\hline & $\begin{array}{l}\text { Audience with } \\
\text { low information } \\
\text { level } \\
\end{array}$ & & To create positive attitude & $\begin{array}{l}\text { TV, newspapers and magazines, } \\
\text { special events, Internet, printing } \\
\text { production and souvenirs }\end{array}$ \\
\hline \multirow[t]{2}{*}{$\cdot \frac{\infty}{0}$} & $\begin{array}{l}\text { Audience } \\
\text { with previous } \\
\text { experience, } \\
\text { relatively } \\
\text { informed } \\
\end{array}$ & \multirow[t]{2}{*}{$\begin{array}{l}\text { To inform, to } \\
\text { draw attention, } \\
\text { to stimulate } \\
\text { actions }\end{array}$} & $\begin{array}{l}\text { To enhance recognisability } \\
\text { and to improve positive } \\
\text { attitude }\end{array}$ & $\begin{array}{l}\text { TV, radio, newspapers and magazines, } \\
\text { outdoor advertisement, special events, } \\
\text { Internet, printing production and } \\
\text { souvenirs }\end{array}$ \\
\hline & $\begin{array}{l}\text { Audience with } \\
\text { low information } \\
\text { level }\end{array}$ & & $\begin{array}{l}\text { To create recognisability } \\
\text { and positive attitude }\end{array}$ & $\begin{array}{l}\text { TV, newspapers and magazines, } \\
\text { special events, Internet, printing } \\
\text { production and souvenirs }\end{array}$ \\
\hline
\end{tabular}

Source: the table is composed by the author 


\section{Conclusions}

Based on the research, conducted in scope of the research, the author has made the following conclusions.

In order to reduce the lag between Latgale region and the other regions of Latvia and to stimulate its social and economic development, it is necessary to use place marketing approach in the working out of region development strategy, based on the determination of real advantages of the region and their positioning according to the needs of the target markets.

As the result of research and generalization of theoretic formulizations of place marketing, the author has systemized and supplemented marketing conception that can be used as a base for planning territory development strategy.

Place marketing is a target-oriented activity that includes market research, product planning, creation, management and promotion in the market in order to satisfy the needs of interested target audiences and to achieve the objectives of the territory in economic and social development. The main feature of place marketing conception is its orientation on different target markets. The objective of market segmentation is to determine the relatively homogenous needs for the territory of each interested group, as each group can be interested in certain advantages or, in terms of place marketing, it can demand a certain product, offered by the territory.

Latgale region has the lowest position amongst other regions of Latvia, as general development is usually evaluated, based on social and economic indicators, that, in turn, has a significant impact on primary attitude base and territory image formation. These indicators provide objective information; however, the target markets are interested in some specific features of the territory that are impossible to reflect objectively in statistical data. These features have been determined by the results of interrogatory researches and used as a base in development of the place marketing strategy.

The place marketing of Latgale region is based on the supply of real territory product to the target markets as well as the development of potential product and the promotion of attractive features in order to inform the target market on distinctive advantages of Latgale region. Today Latgale region can offer the following real products:

- For households target market: ecologically sound environment; schools and educational establishments, their high quality; the availability and quality of banking and financial services as well as telecommunications; the place where relatives and friends live;

- For the businessmen's target market (business environment): geographic location, traditions of production;

- For the visitors' target market: resting outdoors.

- Based on the analysis, the author has developed the following recommendations for Latgale region local government:

- To use place marketing conception for territory management, creating supply that the existing or potential residents, businessmen, investors and the visitors of territory need and are interested in;

- To determine the segments of external and internal target markets of territory, including real, potential and desirable, and to research their needs, interests, priorities and expectations;

- To analyze the resources of territories, to plan their development and improvement in accordance with the needs of the target markets;

- To concentrate place marketing activities on priority groups: households and businessmen, involving both groups in cooperation as well as to inform them on the activities and results;

- To monitor place marketing elements on continuous base, starting from products and services and ending with tourism communication, to coordinate it so that all products of the territory can be recognized outside the territory.

\section{References}

Ashworth, G., Voogd, H. (2007). Place Marketing: Marketing in the Planning and Management of Places. Routledge. Kotler, P. (2004). Attracting investors: a marketing approach to finding funds for your business. Hoboken: Wiley. Kotler, P. (1993). Marketing Places: Attracting Investment, Industry, and Tourism to Cities, States, and Nations. Free Press. 
Olins, W. (2003). Wally Olins on brand. London: Thames and Hudson.

Praude, V., Vozņuka, J. (2008). Classification of Target Market and Features of Segmentation in Marketing Places. Ekonomika, Nr. 81, p. 104-113. Vilniaus universitetas.

Schiff, M., Winters, A. L. (2003). Regional Integration and Development. Oxford University Press.

Vaidere, I., Vanags, E., Vanags, I., Vilka, I. (2006). Reǵionālā politika un pašvaldību attīstība Eiropas Savienībā un Latvijā. Rīga: Latvijas Universitātes Akadēmijas apgāds, Latvijas Statistikas institūts.

Vozṇuka, J. (2008). Latgales reǵiona iedzīvotāju dzīves vietas izvēles faktoru analīze. Latvijas Universitātes raksti. Ekonomika, t. 7, 737.sējums, lpp. 399. -412.

Вознюк, Е. (2008). Маркетинговый подход к стратегическому планированию территории. Current Issues of the Economy and the Management of Business, University of Economics - Varna, Jubilee Scientific and Practical Conference, 27-28 Juna 2008, p. 281-288.

Панкрухин, А. П. (2006). Маркетинг территорий. 2-е изд., дополн. СПб.: Питер.

\title{
LATGALOS REGIONOVIETOS RINKODAROS STRATEGIJA
}

\author{
JEKATERINA VOZNUKA
}

Tarptautinė Baltijos akademija (Latvija)

\section{Santrauka}

Skatinant regionu plètrą galima pasinaudoti rinkodaros priemonėmis, vertinant teritorijos privalumus, kurie svarbūs tikslinei auditorijai. Investuotojų ir turistų pritraukimas, gerų verslo sąlygų vietos verslininkams užtikrinimas taip pat priklauso nuo rinkodaros, todèl jos strategijos rengimas šiuo metu ypač svarbus valstybiniame, regiono ir miesto lygmenyse.

Vietos rinkodara - tai veiksmai, apimantys rinkos tyrimus, produkto kūrimą, valdymą ir rèmimą rinkoje, siekiant patenkinti vartotojų poreikius tam tikroje teritorijoje. Efektyvi vietos rinkodara pritrauktu atitinkamų vartotojų grupę i jų poreikius tenkinanti regioną. Vietos rinkodaros koncepcija gali padėti pasiekti rezultata, nes ji nukreipta į rinkos poreikius - tam tikros vartotoju grupès poreikių nustatymą, kuriuos tenkinant naudos turètų tam tikra teritorija.

Nevienalytė Latvijos regiono plètra yra viena pagrindinių šiandienos problemų. Latgalos regionas užimą paskutinę vietą tarp kitų Latvijos regionų. Ištyrus šį regioną nustatyta, kad jis visiškai pasirengęs taikyti vietos rinkodaros koncepciją, kuriant regiono plètros programas.

Latgalos regione sunkiai tenkinami vietos gyventojų ir verslininkų poreikiai, nes svarbiausi šios tikslinès rinkos veiksniai regione išvystyti silpniausiai. Kiek geriau tenkinami atvykstančiujų i Latgalą poreikiai.

Verslo aplinkos produktą sudaro geografinè padètis, gamybos tradicijos ir rekreaciniai ištekliai Latgalos regione. Efektyvus šių produktų valdymas, pozicionavimas ir rèmimas skatintų pagrindinės tikslinès rinkos pritraukimą ir taip prisidètu prie socialinio ir ekonominio regiono vystymosi. Latgalos regiono vietos rinkodaros strategijos modelis parengtas visoms tikslinėms rinkoms ir apima tokius elementus kaip: segmentavimas, tikslai, pozicionavimas, regiono vystymosi krypčių ir gairių rengimas, bendri komunikacijos kanalai ir priemonès vykdyti integruotą rinkodaros komunikaciją.

PAGRINDINIAI ŽODŽIAI: vystymas, tikslinès rinkos, pozicionavimas, vietine rinkodara.

JEL KLASIFIKACIJA: R190, R580, M310 